\title{
Review Article \\ The Role of Optical Radiations in Skin Cancer
}

\author{
Fabrizio Ayala, Marco Palla, Rossella Di Trolio, Nicola Mozzillo, and Paolo A. Ascierto \\ Department of Melanoma, National Cancer Institute Pascale Foundation, Via Mariano Semmola, 80131 Naples, Italy \\ Correspondence should be addressed to Fabrizio Ayala; fabrizio.ayala@gmail.com
}

Received 12 March 2013; Accepted 1 April 2013

Academic Editors: S. Husz and R. L. Konger

Copyright (C) 2013 Fabrizio Ayala et al. This is an open access article distributed under the Creative Commons Attribution License, which permits unrestricted use, distribution, and reproduction in any medium, provided the original work is properly cited.

\begin{abstract}
Purpose. Electromagnetic radiation with wavelength in the range $100 \mathrm{~nm}$ to $1 \mathrm{~mm}$ is known as optical radiation and includes ultraviolet radiation, the visible spectrum, and infrared radiation. The deleterious short- and long-term biological effects of ultraviolet radiation, including melanoma and other skin cancers, are well recognized. Infrared radiation may also have damaging biological effects. Methods. The objective of this review was to assess the literature over the last 15 years and to summarize correlations between exposure to optical radiation and the risk of melanoma and other cancers. Results. There is a clear correlation between exposure to UV radiation and the development of skin cancer. Most importantly, a strong association between artificial UV radiation exposure, for example, tanning devices, and the risk of melanoma and squamous cell carcinoma has been clearly demonstrated. There is no clear evidence that exposure to IR and laser radiation may increase the risk of skin cancer, although negative health effects have been observed. Conclusions. Preventative strategies that involve provision of public information highlighting the risks associated with exposure to sunlight remain important. In addition, precautionary measures that discourage exposure to tanning appliances are required, as is legislation to prevent their use during childhood.
\end{abstract}

\section{Introduction}

Electromagnetic radiation with wavelength $(\lambda)$ in the range $100 \mathrm{~nm}$ to $1 \mathrm{~mm}$ is known as optical radiation and includes ultraviolet radiation (UV; $100-400 \mathrm{~nm}$ ), through the visible spectrum (380-780 $\mathrm{nm})$ to infrared radiation (IR; $9780 \mathrm{~nm}-$ $1 \mathrm{~mm}$ ) (Figure 1) [1]. UV radiation is subdivided into three regions: UVC (100-280 nm), UVB (280-315 nm), and UVA (315-400), with minimal superimposition over the visible band in the range of $380-400 \mathrm{~nm}$. IR radiation is also further divided into IRA (780-1400 nm), IRB (1400-3000 nm), and IRC $(3000 \mathrm{~nm}-1 \mathrm{~mm})$. These spectral bands, as defined by the International Commission on Illumination (CIE) in 1987 [2], represent the starting point for this consideration of the biologic effects of optical radiation.

1.1. Ultraviolet Radiation. Our planet is subjected to a solar radiation of about $1350 \mathrm{~W} / \mathrm{m}^{2}$, although in reality only around $900 \mathrm{~W} / \mathrm{m}^{2}$ reaches the Earth's surface because of the reflective effect of the stratosphere. Of this amount, the UV component constitutes a limited fraction (around 5\%), since sunlight also consists of visible and infrared bands. The maximum UV radiation measured at ground level is $70 \mathrm{~W} / \mathrm{m}^{2}(4200 \mathrm{~J} / \mathrm{min})$ of UVA, $2.5 \mathrm{~W} / \mathrm{m}^{2}(150 \mathrm{~J} / \mathrm{min})$ of UVB, and almost no UVC [3].

To have a better understanding of the characteristics of UV radiations that reach the Earth's surface, we should consider that at noon on a sunny day along the Mediterranean coast, the solar spectrum contains $95-96 \%$ UVA and $4-5 \%$ of UVB. The intensity of these radiations varies with time and location and is dependent on a range of factors, including hour of the day, season, latitude, altitude, weather, and degree of reflection. Taking these factors into account, the presumed dose of UV that reaches our body at a particular hour, day, and place can be evaluated as an index that is expressed on a scale of 1 to 10 [4]. This UV index is an indicator of the irradiance to the ground on a flat surface and can be used to predict how long people can safely stay exposed to the sun's radiation without deleterious biological effects.

The damaging effects of UV radiation from the sun can be both short term and long term. Some of the adverse effects that are apparent after just a few hours of sunlight exposure 


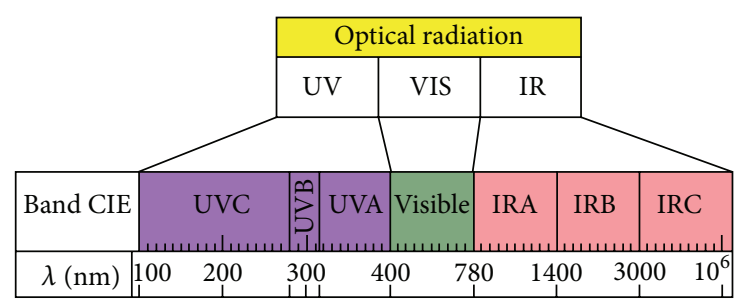

FIGURE 1: Wavelenghts of the main optical radiations.

(e.g., skin redness and burning) are due to the release of substances that cause vasodilation and erythema. Long-term effects include accelerated ageing (photoaging) of the skin, with a loss of elasticity and blotchy appearance, the onset of various skin tumours, cataracts, and also immunodepressive effects.

Cutaneous absorption of UV radiation is limited to the epidermis at wavelengths below $290 \mathrm{~nm}$, while approximately $10 \%$ reaches the dermis in the range of $290-320 \mathrm{~nm}$. About $50 \%$ of UV radiation reaches the cutaneous layer at wavelengths higher than $320 \mathrm{~nm}$, meaning UVA is able to penetrate deeper into the skin than UVB. Since UVA also constitutes most of the UV spectrum reaching the Earth's surface, more UVA than UVB reaches the basal layers of the epidermis where keratinocytic stem cells and melanocytes are located [5].

Many studies have confirmed the mutagenic property of UV radiation [5-11]. UVB rays are carcinogenic agents that are directly absorbed by DNA and cause direct damage. This typically includes the formation of cyclobutane pyrimidine (CPD) dimers and 6-4 photoproducts (6-4P). Mutations induced by UVB are conversions such as $\mathrm{C} \rightarrow \mathrm{T}$ and $\mathrm{CC} \rightarrow$ TT, commonly named the "UVB fingerprint" or "UVB signature." UVB can also induce the formation of singlet oxygen $\left(\mathrm{O}^{2-}\right)$, an extremely reactive oxidative compound that can indirectly damage DNA [12]. A recent study also suggested that $\mathrm{C} \rightarrow \mathrm{T}$ conversion can be induced by UVA [13].

Unlike UVB, UVA is not absorbed by DNA and so has no direct effect. Instead, UVA indirectly induces damage to DNA through the absorption of photons by other cell structures (chromophores) and the subsequent formation of oxygen reactive species (singlet oxygen and hydrogen peroxide). These principally react with guanine, thereby inducing DNA mutations. This damage is characterized by $\mathrm{T} \rightarrow \mathrm{G}$ conversions, known as "UVA fingerprint" or "UVA signature" mutations [14].

UVA and UVB cause cellular damage through different mechanisms $[15,16]$, although both act on expression of P53 and bcl-2 proteins that are involved in the regulation of apoptosis induced by UV radiation [17-20]. In fact, mutations in the P53 gene have been noticed both in basal cell carcinoma (BCC) $[21,22]$ and in squamous cell carcinoma (SCC) [23, 24]. Several studies have proven a pathogenetic correlation between UV radiation and skin cancer [25-29].

1.2. Infrared Radiation and Lasers. The International Commission on Nonionizing Radiation Protection (ICNIRP) offers limited information on trends in human exposure to IR radiations [30]. In recent years though, new types of IR heating devices, for example, dish warmers, infrared heating boxes (known as IR sauna) have been introduced for domestic use. Very little is known about the biologic effects of IR radiation, even though skin has considerable exposure to both natural and artificial sources. Epidemiologic and clinical data suggest that IR radiation is involved in the process of premature skin ageing and carcinogenesis, indicating that IR exposure is not entirely safe $[31,32]$. It is worth noting that the damaging effects of RI radiation on crystalline lens through the action of heat in the iris are well recognized (e.g., in the high prevalence of cataracts observed in glass blowers).

The acronym L.A.S.E.R. (Light Amplification by Stimulated Emission of Radiation) refers to electromagnetic nonionizing radiations. Unlike ionizing radiations, the energy of nonionizing ones is not sufficient to ionize atoms and molecules by modifying bonds. However, they can break chemical bonds by means of photochemical reactions.

\section{Materials and Methods}

Data in this review have been extracted from reports and studies from the major international professional bodies and committees, including the International Commission on Nonionizing Radiation Protection (ICNIRP), the International Commission on Illumination (CIE), the World Health Organization (WHO), the INTERSUN Programme, the International Agency for Research on Cancer (IARC), the US. Environmental Protection Agency SunWise Program, the National Weather Service-Climate Prediction Center (NWSCPC), the United Nations Environment Programme (UNEP), the World Meteorologic Organization (OMM), and the Electrotechnical International Committee.

These data have been complemented by a systematic literature review, in which various combinations of keywords have been used to search MEDLINE and identify relevant publications. These keywords consisted of ultraviolet radiation, UVR, infrared radiation, IR, cancer, tumor, skin cancer, melanoma, basal cell carcinoma, BCC, squamous cell carcinoma, SCC, sun tanning, sunburn, solaria, sunlamp, sunbed, artificial UV, laser, Nd:YAG, diode, Alexandrite, carbon dioxide, ruby, erbium:YAG, pulsed dye, and argon.

\section{Results}

3.1. Solar Exposure. Table 1 summarizes the principal studies that have investigated the association between UV radiation and skin cancer [33-43]. In many epidemiological studies, exposure to UV solar radiations has been recognized as the main environmental or behavioural cause for the appearance of melanoma. Although a dose-response type relationship between UV radiation exposure and the risk of melanoma is not always demonstrable because of confounding patientspecific variables, such as phototype and tendency to develop moles [41-44], excessive cumulative solar exposure (total lifetime hours) is well proven as the main causal factor in the pathogenesis of melanoma [45]. In particular, there is a strong 
TABLE 1: Main published studies on association between solar UV exposure and the risk of melanoma, basal cell and squamous cell, carcinoma onset.

\begin{tabular}{|c|c|c|c|}
\hline Reference & Type of exposure & $\begin{array}{l}\text { Epidemiological index } \\
\text { Odds ratio }(95 \% \mathrm{CI}) \\
\end{array}$ & Comment \\
\hline \multicolumn{4}{|c|}{ Melanoma } \\
\hline White et al. (1994) [33] & Chronic & $0.3(0.16-0.59)$ & Exposure aged 2-20 years \\
\hline \multirow{3}{*}{$\begin{array}{l}\text { Mark Elwood and Jopson } \\
\text { (1997) [34] }\end{array}$} & Chronic (occupational) & $0.86(0.77-0.96)$ & \multirow{3}{*}{ Meta-analysis of 29 studies } \\
\hline & Intermittent & $1.71(1.54-1.90)$ & \\
\hline & Total & $1.18(1.02-1.38)$ & \\
\hline \multirow{2}{*}{ Autier and Doré (1998) [35] } & $\begin{array}{l}>1 \text { year tropical or subtropical } \\
\text { area }\end{array}$ & $4.3(1.7-11.1)$ & Exposure aged $<10$ years \\
\hline & $\begin{array}{l}>1 \text { year tropical or subtropical } \\
\text { area }\end{array}$ & $4.1(1.3-13.4)$ & $\begin{array}{l}\text { Exposure in adolescence or } \\
\text { adulthood }\end{array}$ \\
\hline \multirow{2}{*}{ Walter et al. (1999) [36] } & Chronic & $0.67(0.52-0.85)$ & \multirow{2}{*}{ Exposure aged $<18$ years } \\
\hline & Intermittent & $1.67(1.31-2.12)$ & \\
\hline \multirow{2}{*}{ Kaskel et al. (2001) [37] } & Chronic & $0.3(0.1-1.1)$ & \multirow{2}{*}{ Exposure aged $<12$ years } \\
\hline & Intermittent & $2.4(1.2-4.9)$ & \\
\hline \multirow{2}{*}{ Whiteman et al. (2006) [38] } & Chronic & $2.49(1.12-5.54)$ & \multirow{2}{*}{ Head and neck } \\
\hline & Intermittent & $0.38(0.17-0.83)$ & \\
\hline \multirow{3}{*}{ Kricker et al. (2007) [39] } & Chronic & 1.03 & \multirow{3}{*}{ Multiple versus single melanoma } \\
\hline & Intermittent (beach) & 1.85 & \\
\hline & Intermittent (recreational) & 1.38 & \\
\hline \multirow{2}{*}{ Nagore et al.(2010) [40] } & Chronic $(<20$ years $)$ & $0.6(0.3-1.3)$ & \multirow{2}{*}{ Age at diagnosis $>60$ years } \\
\hline & Chronic (>20 years) & $2.1(1.1-4.0)$ & \\
\hline \multicolumn{4}{|c|}{ Basal cell (BCC) and squamous cell carcinoma (SCC) } \\
\hline \multirow{8}{*}{$\begin{array}{l}\text { Armstrong and Kricker } \\
(2001)[41]\end{array}$} & $B C C:$ & & \multirow{8}{*}{ Meta-analysis } \\
\hline & Chronic & $1.19(1.07-1.32)$ & \\
\hline & Intermittent & $1.38(1.24-1.54)$ & \\
\hline & Total & $0.98(0.68-1.41)$ & \\
\hline & SCC: & & \\
\hline & Chronic & $1.64(1.26-2.13)$ & \\
\hline & Intermittent & $0.91(0.68-1.22)$ & \\
\hline & Total & $1.53(1.02-2.27)$ & \\
\hline \multirow{8}{*}{ Zanetti et al. (2006) [42] } & BCC: & & \\
\hline & Chronic (occupational) & $1.2(0.70-2.13)$ & \\
\hline & Intermittent & $1.3(0.72-2.39)$ & \\
\hline & Total & $1.7(0.97-3.03)$ & \\
\hline & SCC: & & \\
\hline & Chronic (occupational) & $2.2(1.13-4.08)$ & \\
\hline & Intermittent & $0.6(0.29-1.21)$ & \\
\hline & Total & $1.8(0.95-3.32)$ & \\
\hline \multirow{2}{*}{ Han et al. (2006) [43] } & BCC total & $1.95(1.34-2.83)$ & \\
\hline & SCC total & $1.97(1.37-2.85)$ & \\
\hline
\end{tabular}

correlation between the onset of melanoma and intense intermittent exposures or number of sunburn episodes. The relative risk of melanoma is significantly increased if these events happen during childhood and adolescence rather than in adult life (odds ratio (OR) 4.3 [1.7-11.1]) [35].
The pattern of exposure to solar radiations is a key determining factor in the occurrence of melanoma [46]. Most studies confirm a direct correlation between recreational or intermittent sun exposure and melanoma onset. For instance, in a meta-analysis of 29 case-control studies which 
assessed incident melanoma, sun exposure, and sunburn, Mark Elwood and Jopson (1997) reported an OR of 1.71 associated with intermittent solar exposure [34]. Conversely, an inverse correlation (i.e., a protective effect) was shown for heavy occupational exposure (OR 0.86). Another metaanalysis that included 57 studies also showed a protective effect of continuous exposure, especially in people who easily tan and rarely burn [47]. Indeed, many studies confirm the protective effect of continuous solar exposure during childhood and adolescence, particularly in individuals with phototype III-IV [33, 37], while excessive exposures, especially in people with fair skin and in the first 10 years of life, is associated with an increased risk of melanoma in later life [41, 48, 49]. Interestingly, some studies have indicated that artificially induced suntan, for example, before holidays/increased exposure to sunlight, has minimal to no protection against DNA damage [50-52].

Recent epidemiological studies have also demonstrated that solar UV radiations have a role in the onset of melanoma of the conjunctiva and iris (ocular melanoma), with pathogenetic mechanisms similar to those of cutaneous melanoma (OR 3.5 [1.2-8.9]) [53, 54]. The frequent confinement to the lower area of the iris confirms the role of UV radiations [55]. There is only a limited correlation between exposure to UV solar radiations and melanoma of the ciliary body and choroid, ocular areas not directly exposed to sunlight (OR 1.1 [0.7-1.6]) [56].

In addition to melanoma, both BCC and SCC are associated with UV radiation exposure. BCC is doubtless the most frequent skin cancer and UV rays represent the main cause of its onset [57]. The pattern of intermittent solar exposure and high doses of UV during childhood are more apparent in patients affected by BCC $[37,44,45]$, whereas SCC is more strongly correlated with high doses of total or chronicworking exposures [44, 45].

3.2. Artificial UV Exposure: Sunbeds and Sunlamps. Since 2003-2004, when the US National Toxicology Program report on carcinogenesis recognized and classified total UV radiations as a carcinogenic agent for man [59], attention has been focused on the possible correlation between artificial exposure to UV radiations and skin cancer. As a result, in 2005, the IARC asked a group of experts to conduct a metaanalysis of studies assessing the correlation between artificial UV exposure and skin cancers. Their report, published in 2006, represents the most up-to-date document on this topic [58].

The results of their meta-analysis, which identified 19 studies with estimates of the relative risk (RR) for cutaneous melanoma associated with exposure to tanning appliances, are summarized in Table 2. The RR of melanoma associated with use of an indoor tanning facility was 1.15 (1.00-1.31). When the analysis was narrowed to include only the ten population-based case-control $(n=9)$ and cohort $(n=1)$ studies (i.e., excluding hospital-based studies), RR was 1.17 (0.96-1.42). When first exposure in youth (before age 35 years) was analyzed (7 studies), a significant $75 \%$ increase in risk was observed (RR 1.75 [1.35-2.26]). For this reason, a
TABLE 2: Results of IARC meta-analysis of studies on the correlation between sun lamp exposure and the risk of melanoma, basal cell carcinoma, and squamous cell carcinoma onset [58].

\begin{tabular}{|c|c|c|c|}
\hline & $\begin{array}{l}\text { Studies } \\
(n)\end{array}$ & $\begin{array}{c}\text { Relative risk } \\
(95 \% \mathrm{CI})\end{array}$ & $\begin{array}{c}\text { Heterogeneity } \\
P \text { value } \chi^{2}\end{array}$ \\
\hline \multicolumn{4}{|l|}{ Melanoma } \\
\hline Sun lamp exposure & 19 & $\begin{array}{c}1.15 \\
(1.00-1.31)\end{array}$ & 0.013 \\
\hline $\begin{array}{l}\text { First exposure in young } \\
\text { age }\end{array}$ & 7 & $\begin{array}{c}1.75 \\
(1.35-2.26)\end{array}$ & 0.55 \\
\hline Past exposure & 5 & $\begin{array}{c}1.49 \\
(0.93-2.38)\end{array}$ & 0.018 \\
\hline Recent exposure & 5 & $\begin{array}{c}1.10 \\
(0.76-1.60)\end{array}$ & 0,05625 \\
\hline \multicolumn{4}{|l|}{ Basal cell carcinoma } \\
\hline Sun lamp exposure & 4 & $\begin{array}{c}1.03 \\
(0.56-1.90)\end{array}$ & 0.06 \\
\hline \multicolumn{4}{|l|}{ Squamous cell carcinoma } \\
\hline Sun lamp exposure & 3 & $\begin{array}{c}2.25 \\
(1.08-4.70)\end{array}$ & 0.10 \\
\hline
\end{tabular}

recent report from IARC reclassified these devices as being among those that emit radiations carcinogenic to humans (Group 1) [60]. No strong evidence concerning a doseresponse relationship between artificial UV exposure and risk of melanoma was identified.

The IARC also assessed the relationship between SCC and $\mathrm{BCC}$ and exposure to artificial UV radiation. Indoor tanning was shown to significantly increase the risk of SCC (three studies; RR 2.25 [1.08-4.70]), but no effect was observed for BCC (four studies; RR 1.03 [0.56-1.90]) [60].

3.3. UVB Devices for Phototherapy. Artificial UVB devices are used to treat many cutaneous diseases, in particular psoriasis. This has typically involved the use of wide-band UVB, although narrow-band devices have also recently been shown to be beneficial. Studies have shown no significant relation between the use of UVB devices for phototherapy and the incidence of melanoma, BCC, or SCC [61-68]. Nevertheless, although these data may seem reassuring, they cannot exclude the possibility of an increased tumour risk in patients receiving high doses of UVB [69].

3.4. PUVA Therapy. PUVA therapy involves the combination of psoralen, a light-sensitizing medication, with UVA and is used in the treatment of psoriasis and other skin conditions. Overall, there appears to be good evidence that PUVA increases the risk of SCC, although it can be difficult to identify causality since patients often receive several other potentially carcinogenic treatments. Two cohort studies have reported an association between PUVA therapy and skin cancer: one that included 4799 patients in Sweden [70], and a second that included 1380 patients in the USA [71]. In the Swedish study, the RR of SCC onset was 5.6 (4.47.1) in men and $3.6(2.1-5.8)$ in women. In the US cohort, approximately one-quarter of patients who had received 
more than $2000 \mathrm{~J} / \mathrm{cm}^{2}$ developed SCC. A meta-analysis by the same group reported that patients exposed to high doses of PUVA (more than 200 treatments or more than $2000 \mathrm{~J} / \mathrm{cm}^{2}$ ) had a risk 14 times higher than those treated with less than 100 sessions or exposed to less than $1000 \mathrm{~J} / \mathrm{cm}^{2}$ [72]. Another recent 30-year prospective study showed that receiving between 350 and 450 PUVA treatments had an RR of 6.0 (4.48.2) for SCC compared with less than 50 treatments. However, even high-dose exposure did not increase BCC risk [73].

The risk of melanoma onset associated with PUVA is more controversial. The American cohort study [71] reported an increased risk of melanoma, with patients exposed to more than 200 treatments compared to lower doses having an almost threefold greater risk (RR 2.9 [1.3-6.4]). Moreover, this risk increased over time, with an incident relative risk of 5.0 (1.6-15.5) among patients after $>15$ years followup (versus $<15$ years). In the Swedish cohort, an increased risk for melanoma was not observed. Since the Swedish study is both larger and has a longer period of followup (on average 16 years), data obtained from this cohort are the more convincing.

3.5. Exposure to Infrared and Laser Radiations. As with UV radiation, extended exposure (15-20 years) to IR radiation can induce actinic keratosis, a possible precursor to in situ or invasive carcinomas. It is also known that prolonged exposure of the skin to heat induces particular changes known as warmer erythema, heat dermatitis, or erythema ab igne. However, there are only limited data on the topic of IR radiation and cancers (in particular of the skin), with most being case reports of tumours arising secondarily to erythema $a b$ igne after many years [73-87].

At the present moment there are no studies that demonstrate potential carcinogenicity of laser devices, although this could depend on the relative rare occurrence of exposure to laser beams. There are case reports in the literature concerning malignant tumours arising from benign lesions after prolonged laser treatments. However, the possibility of diagnostic error before laser therapy cannot be excluded in these rare cases [88-97].

\section{Conclusions}

Our review of the literature shows a clear association between UV radiation exposure and increased risk of melanoma and other skin cancers. However, there is no clear evidence of any relationship between skin cancer and IR or laser radiations.

Preventative strategies that include public information campaigns to highlight the risks associated with exposure to sunlight, including the degree of exposure that is considered acceptable with regard to health and identifying patient types most at risk, remain important. The use of artificial tanning devices requires special consideration. It is now clear that there is a strong association between these devices and the risk of melanoma and SCC. As such, precautionary measures that discourage exposure to tanning appliances, especially among younger people, are required, as is legislation to prevent their use during childhood. Public health initiatives comparative to those that have successfully targeted cigarette smoking are now needed to limit recreational exposure to artificial UV sources.

\section{References}

[1] Sicurezza and Energia Multiservice, "Radiazioni Ottiche," http://www.sicurezzaenergia.com/Sicurezza-sul-lavoro/Radiazioni-ottiche.php.

[2] "International Commission on Illumination," http://www.cie co.at

[3] World Health Organization, "Ultraviolet radiation and health," http://www.who.int/uv/uv_and_health/en/index.html.

[4] World Health Organization, "Global solar UV index," http:// www.who.int/mediacentre/factsheets/fs305/en/index.html.

[5] N. S. Agar, G. M. Halliday, R. S. C. Barnetson, H. N. Ananthaswamy, M. Wheeler, and A. M. Jones, "The basal layer in human squamous tumors harbors more UVA than UVB fingerprint mutations: a role for UVA in human skin carcinogenesis," Proceedings of the National Academy of Sciences of the United States of America, vol. 101, no. 14, pp. 4954-4959, 2004.

[6] C. Robert, B. Muel, A. Benoit, L. Dubertret, A. Sarasin, and A. Stary, "Cell survival and shuttle vector mutagenesis induced by ultraviolet A and ultraviolet B radiation in a human cell line," Journal of Investigative Dermatology, vol. 106, no. 4, pp. 721-728, 1996.

[7] S. Pavel, N. P. M. Smit, H. Van Der Meulen et al., "Homozygous germline mutation of $\mathrm{CDKN} 2 \mathrm{~A} / \mathrm{p} 16$ and glucose-6phosphate dehydrogenase deficiency in a multiple melanoma case," Melanoma Research, vol. 13, no. 2, pp. 171-178, 2003.

[8] G. P. Pfeifer, Y. H. You, and A. Besaratinia, "Mutations induced by ultraviolet light," Mutation Research, vol. 571, no. 1-2, pp. 1931, 2005.

[9] G. M. Halliday, "Inflammation, gene mutation and photoimmunosuppression in response to UVR-induced oxidative damage contributes to photocarcinogenesis," Mutation Research, vol. 571, no. 1-2, pp. 107-120, 2005.

[10] G. M. Halliday, N. S. Agar, R. S. C. Barnetson, H. N. Ananthaswamy, and A. M. Jones, "UV-A fingerprint mutations in human skin cancer," Photochemistry and Photobiology, vol. 81, no. 1, pp. 3-8, 2005.

[11] A. J. Ridley, J. R. Whiteside, T. J. McMillan, and S. L. Allinson, "Cellular and sub-cellular responses to UVA in relation to carcinogenesis," International Journal of Radiation Biology, vol. 85, no. 3, pp. 177-185, 2009.

[12] H. R. Griffiths, P. Mistry, K. E. Herbert, and J. Lunec, "Molecular and cellular effects of ultraviolet light-induced genotoxicity," Critical Reviews in Clinical Laboratory Sciences, vol. 35, no. 3, pp. 189-237, 1998.

[13] T. M. Rünger, " $\mathrm{C} \rightarrow \mathrm{T}$ transition mutations are not solely UVBsignature mutations, because they are also generated by UVA," Journal of Investigative Dermatology, vol. 128, no. 9, pp. 21382140, 2008.

[14] E. A. Drobetsky, J. Turcotte, and A. Châteauneuf, "A role for ultraviolet A in solar mutagenesis," Proceedings of the National Academy of Sciences of the United States of America, vol. 92, no. 6, pp. 2350-2354, 1995.

[15] R. Nishigaki, H. Mitani, N. Tsuchida, and A. Shima, "Effect of cyclobutane pyrimidine dimers on apoptosis induced by different wavelengths of UV," Photochemistry and Photobiology, vol. 70, no. 2, pp. 228-235, 1999. 
[16] H. Zhang and I. Rosdahl, "Ultraviolet A and B differently induce intracellular protein expression in human skin melanocytes: a speculation of separate pathways in initiation of melanoma," Carcinogenesis, vol. 24, no. 12, pp. 1929-1934, 2003.

[17] A. Woollons, P. H. Clingen, M. L. Price, C. F. Arlett, and M. H. L. Green, "Induction of mutagenic DNA damage in human fibroblasts after exposure to artificial tanning lamps," British Journal of Dermatology, vol. 137, no. 5, pp. 687-692, 1997.

[18] Y. Wang, B. Rosenstein, S. Goldwyn, X. Zhang, M. Lebwohl, and $\mathrm{H}$. Wei, "Differential regulation of P53 and Bcl-2 expression by ultraviolet A and B," Journal of Investigative Dermatology, vol. 111, no. 3, pp. 380-384, 1998.

[19] S. E. Whitmore, W. L. Morison, C. S. Potten, and C. Chadwick, "Tanning salon exposure and molecular alterations," Journal of the American Academy of Dermatology, vol. 44, no. 5, pp. 775780, 2001.

[20] Å. E. Persson, D. W. Edström, H. Bäckvall et al., "The mutagenic effect of ultraviolet-A1 on human skin demonstrated by sequencing the p53 gene in single keratinocytes," Photodermatology Photoimmunology and Photomedicine, vol. 18, no. 6, pp. 287-293, 2002.

[21] M. Šitum, M. Buljan, V. Bulat, Z. Bolanèa, and D. Simic, "The role of UV radiation in the development of Basal cell carcinoma," Collegium Antropologicum, vol. 32, no. SUPPL. 2, pp. 167-170, 2008.

[22] M. R. Gailani, D. J. Leffell, A. Ziegler, E. G. Gross, D. E. Brash, and A. E. Bale, "Relationship between sunlight exposure and a key genetic alteration in basal cell carcinoma," Journal of the National Cancer Institute, vol. 88, no. 6, pp. 349-354, 1996.

[23] C. L. Benjamin, V. O. Melnikova, and H. N. Ananthaswamy, "P53 protein and pathogenesis of melanoma and nonmelanoma skin cancer," Advances in Experimental Medicine and Biology, vol. 624, pp. 265-282, 2008.

[24] A. Pacifico and G. Leone, "Role of p53 and CDKN2A inactivation in human squamous cell carcinomas," Journal of Biomedicine and Biotechnology, vol. 2007, Article ID 43418, 5 pages, 2007.

[25] T. M. Rünger, "How different wavelengths of the ultraviolet spectrum contribute to skin carcinogenesis: the role of cellular damage responses," Journal of Investigative Dermatology, vol. 127, no. 9, pp. 2103-2105, 2007.

[26] J. Moan, A. C. Porojnicu, and A. Dahlback, "Ultraviolet radiation and malignant melanoma," Advances in Experimental Medicine and Biology, vol. 624, pp. 104-116, 2008.

[27] D. C. Bennett, "Ultraviolet wavebands and melanoma initiation," Pigment Cell and Melanoma Research, vol. 21, no. 5, pp. 520-524, 2008.

[28] L. Marrot and J. R. Meunier, "Skin DNA photodamage and its biological consequences," Journal of the American Academy of Dermatology, vol. 58, no. 5, pp. S139-S148, 2008.

[29] T. M. Rünger and U. P. Kappes, "Mechanisms of mutation formation with long-wave ultraviolet light (UVA)," Photodermatology Photoimmunology and Photomedicine, vol. 24, no. 1, pp. 2-10, 2008.

[30] International Commission on Non-Ionizing Radiation Protection, "Guidelines on limits of exposure to laser radiation of wavelengths between $180 \mathrm{~nm}$ and 1,000 nm," Health Physics, vol. 71, no. 5, pp. 804-814, 1996.

[31] L. H. Klingman and A. M. Klingman, "Reflection on heat," British Journal of Dermatology, vol. 110, no. 3, pp. 369-375, 1984.
[32] J. S. Dover, T. J. Philips, and K. A. Arndt, "Cutaneous effects and therapeutic uses of heat with emphasis on infrared radiation," Journal of the American Academy of Dermatology, vol. 20, no. 2 I, pp. 278-286, 1989.

[33] E. White, C. S. Kirkpatrick, and J. A. H. Lee, "Case-control study of malignant melanoma in Washington State. I. Constitutional factors and sun exposure," The American Journal of Epidemiology, vol. 139, no. 9, pp. 857-868, 1994.

[34] J. Mark Elwood and J. Jopson, "Melanoma and sun exposure: an overview of published studies," International Journal of Cancer, vol. 73, no. 2, pp. 198-203, 1997.

[35] P. Autier and J.-F. Doré, "Influence of sun exposures during childhood and during adulthood on melanoma risk," International Journal of Cancer, vol. 77, no. 4, pp. 533-537, 1998.

[36] S. D. Walter, W. D. King, and L. D. Marrett, "Association of cutaneous malignant melanoma with intermittent exposure to ultraviolet radiation: results of a case-control study in Ontario, Canada," International Journal of Epidemiology, vol. 28, no. 3, pp. 418-427, 1999.

[37] P. Kaskel, S. Sander, M. Kron, P. Kind, R. U. Peter, and G. Krähn, "Outdoor activities in childhood: a protective factor for cutaneous melanoma? Results of a case-control study in 271 matched pairs," British Journal of Dermatology, vol. 145, no. 4, pp. 602-609, 2001.

[38] D. C. Whiteman, M. Stickley, P. Watt, M. C. Hughes, M. B. Davis, and A. C. Green, "Anatomic site, sun exposure, and risk of cutaneous melanoma," Journal of Clinical Oncology, vol. 24, no. 19, pp. 3172-3177, 2006.

[39] A. Kricker, B. K. Armstrong, C. Goumas et al., "Ambient UV, personal sun exposure and risk of multiple primary melanomas," Cancer Causes and Control, vol. 18, no. 3, pp. 295304, 2007.

[40] E. Nagore, L. Hueso, R. Botella-Estrada et al., "Smoking, sun exposure, number of nevi and previous neoplasias are risk factors for melanoma in older patients (60 years and over)," Journal of the European Academy of Dermatology and Venereology, vol. 24 , no. 1, pp. 50-57, 2010.

[41] B. K. Armstrong and A. Kricker, "The epidemiology of UV induced skin cancer," Journal of Photochemistry and Photobiology B, vol. 63, no. 1-3, pp. 8-18, 2001.

[42] R. Zanetti, S. Rosso, C. Martinez et al., "Comparison of risk patterns in carcinoma and melanoma of the skin in men: a multi-centre case-case-control study," British Journal of Cancer, vol. 94, no. 5, pp. 743-751, 2006.

[43] J. Han, G. A. Colditz, and D. J. Hunter, "Risk factors for skin cancers: a nested case-control study within the Nurses' Health Study," International Journal of Epidemiology, vol. 35, no. 6, pp. 1514-1521, 2006.

[44] J. M. Elwood, R. P. Gallagher, G. B. Hill, and J. C. G. Pearson, "Cutaneous melanoma in relation to intermittent and constant sun exposure: the Western Canada melanoma study," International Journal of Cancer, vol. 35, no. 4, pp. 427-433, 1985.

[45] R. M. MacKie, "Incidence, risk factors and prevention of melanoma," European Journal of Cancer, vol. 34, supplement 3, pp. S3-S4, 1998.

[46] B. K. Armstrong, "How sun exposure causes skin cancer: an epidemiological perspective," in Prevention of Skin Cancer: Cancer Prevention, Cancer Causes, D. Hill, J. M. Elwood, and D. R. English, Eds., Kluwer Academic Publishers, Boston, Mass, USA, 2004. 
[47] S. Gandini, F. Sera, M. S. Cattaruzza et al., "Meta-analysis of risk factors for cutaneous melanoma: II. Sun exposure," European Journal of Cancer, vol. 41, no. 1, pp. 45-60, 2005.

[48] P. Autier, G. Severi, R. Pedeux et al., "Number and size of nevi are influenced by different sun exposure components: implications for the etiology of cutaneous melanoma (Belgium, Germany, France, Italy)," Cancer Causes and Control, vol. 14, no. 5, pp. 453-459, 2003.

[49] D. C. Whiteman, C. A. Whiteman, and A. C. Green, "Childhood sun exposure as a risk factor for melanoma: a systematic review of epidemiologic studies," Cancer Causes and Control, vol. 12, no. 1, pp. 69-82, 2001.

[50] K. Hemminki, V. J. Bykov, J. A. Marcusson, P. Autier, R. Pedeux, and J. F. Dore, "Re: sunscreen use and duration of sun exposure: a double-blind, randomized trial," Journal of the National Cancer Institute, vol. 91, no. 23, pp. 2046-2047, 1999.

[51] V. J. Bykov, J. A. Marcusson, and K. Hemminki, "Protective effects of tanning on cutaneous DNA damage in situ," Dermatology, vol. 202, no. 1, pp. 22-26, 2001.

[52] J. Ruegemer, B. Schuetz, K. Hermann, R. Hein, J. Ring, and D. Abeck, "UV-induced skin changes due to regular use of commercial sunbeds," Photodermatology Photoimmunology and Photomedicine, vol. 18, no. 5, pp. 223-227, 2002.

[53] D.-N. Hu, "Photobiology of ocular melanocytes and melanoma," Photochemistry and Photobiology, vol. 81, no. 3, pp. 506-509, 2005.

[54] C. M. Vajdic, A. Kricker, M. Giblin et al., "Sun exposure predicts risk of ocular melanoma in Australia," International Journal of Cancer, vol. 101, no. 2, pp. 175-182, 2002.

[55] J. A. Shields and S. C. Shields, Intraocuiar Tumor: A Text and Atlas, WB Saunders, Philadelphia, Pa, USA, 1992.

[56] A. D. Singh, I. G. Rennie, S. Seregard, M. Giblin, and J. McKenzie, "Sunlight exposure and pathogenesis of uveal melanoma," Survey of Ophthalmology, vol. 49, no. 4, pp. 419-428, 2004.

[57] R. E. Neale, M. Davis, N. Pandeya, D. C. Whiteman, and A. C. Green, "Basal cell carcinoma on the trunk is associated with excessive sun exposure," Journal of the American Academy of Dermatology, vol. 56, no. 3, pp. 380-386, 2007.

[58] IARC, "Exposure to artificial UV radiation and skin cancer/views and expert opinions of an IARC Working Group that met in Lyon, France 27-29 June 2005," International Agency for Research on Cancer, 2006.

[59] National Toxicology Program, "Ultraviolet radiation related exposures: broad-spectrum ultraviolet (UV) radiation, UVA, UVB, UVC, solar radiation, and exposure to sunlamps and sunbeds," Report on Carcinogens, vol. 10, pp. 250-254, 2002.

[60] F. El Ghissassi, R. Baan, K. Straif et al., "A review of human carcinogens. Part D: radiation," The lancet oncology, vol. 10, no. 11, pp. 751-752, 2009.

[61] W. Z. Maughan, S. A. Muller, and H. O. Perry, "Incidence of skin cancers in patients with atopic dermatitis treated with coal tar. A 25-year follow-up study," Journal of the American Academy of Dermatology, vol. 3, no. 6, pp. 612-615, 1980.

[62] M. R. Pittelkow, H. O. Perry, S. A. Muller, W. Z. Maughan, and P. C. O'Brien, "Skin cancer in patients with psoriasis treated with coal Tar. A 25-year follow-up study," Archives of Dermatology, vol. 117, no. 8, pp. 465-468, 1981.

[63] K. M. Halprin, M. Comerford, and J. R. Taylor, "Cancer in patients with psoriasis," Journal of the American Academy of Dermatology, vol. 7, no. 5, pp. 633-638, 1982.
[64] O. Larko and G. Swanbeck, "Is UVB treatment of psoriasis safe? A study of extensively UVB-treated psoriasis patients compared with a matched control group," Acta Dermato-Venereologica, vol. 62, supplement, no. 6, pp. 507-512, 1982.

[65] S. M. Bhate, G. R. Sharpe, J. M. Marks, S. Shuster, and W. M. Ross, "Prevalence of skin and other cancers in patients with psoriasis," Clinical and Experimental Dermatology, vol. 18, no. 5, pp. 401-404, 1993.

[66] R. S. Stern and N. Laird, "The carcinogenic risk of treatments for severe psoriasis. Photochemotherapy Follow-up Study," Cancer, vol. 73, pp. 2759-2764, 1994.

[67] M. Weischer, A. Blum, F. Eberhard, M. Röcken, and M. Berneburg, "No evidence for increased skin cancer risk in psoriasis patients treated with broadband or narrowband UVB phototherapy: a first retrospective study," Acta DermatoVenereologica, vol. 84, no. 5, pp. 370-374, 2004.

[68] E. Lee, J. Koo, and T. Berger, "UVB phototherapy and skin cancer risk: a review of the literature," International Journal of Dermatology, vol. 44, no. 5, pp. 355-360, 2005.

[69] R. M. R. Hearn, A. C. Kerr, K. F. Rahim, J. Ferguson, and R. S. Dawe, "Incidence of skin cancers in 3867 patients treated with narrow-band ultraviolet B phototherapy," British Journal of Dermatology, vol. 159, no. 4, pp. 931-935, 2008.

[70] B. Lindelöf, B. Sigurgeirsson, E. Tegner et al., "PUVA and cancer risk: the Swedish follow-up study," British Journal of Dermatology, vol. 141, no. 1, pp. 108-112, 1999.

[71] R. S. Stern, "The risk of melanoma in association with longterm exposure to PUVA," Journal of the American Academy of Dermatology, vol. 44, no. 5, pp. 755-761, 2001.

[72] R. S. Stern and E. J. Lunder, "Risk of squamous cell carcinoma and methoxsalen (psoralen) and UV-A radiation (PUVA): a meta-analysis," Archives of Dermatology, vol. 134, no. 12, pp. 1582-1585, 1998.

[73] R. S. Stern, "PUVA Follow-Up Study. The risk of squamous cell and basal cell cancer associated with psoralen and ultraviolet $\mathrm{A}$ therapy: a 30-year prospective study," Journal of the American Academy of Dermatology, vol. 66, no. 4, pp. 553-562, 2012.

[74] J. A. Bain, H. P. Rusch, and B. E. Kline, "The effect of temperature upon ultraviolet carcinogenesis with wavelength 2.800 3.400 Å," Cancer Research, vol. 3, pp. 610-612, 1943.

[75] G. A. G. Peterkin, "Malignant changes in erythema ab igne," British Medical Journal, vol. 31, no. 2, pp. 1599-1602, 1955.

[76] R. G. Freeman and J. M. Knox, "Influence of temperature on ultraviolet injury," Archives of dermatology, vol. 89, pp. 858-864, 1964.

[77] G. R. Finlayson, W. M. Sams Jr., and J. G. Smith, "Erythema ab igne: a histopathological study," Journal of Investigative Dermatology, vol. 46, no. 1, pp. 104-108, 1966.

[78] F. Cross, "On a turf (peat) fire cancer: malignant change superimposed on erythema ab igne," Proceedings of the Royal Society of Medicine, vol. 60, no. 12, pp. 1307-1308, 1967.

[79] J. H. Arrington III and D. S. Lockman, "Thermal keratoses and squamous cell carcinoma in situ associated with erythema ab igne," Archives of Dermatology, vol. 115, no. 10, pp. 1226-1228, 1979.

[80] L. H. Kligman, "Intensification of ultraviolet-induced dermal damage by infrared radiation," Archives of Dermatological Research, vol. 272, no. 3-4, pp. 229-238, 1982.

[81] C. S. Jones, S. K. Tyring, P. C. Lee, and J. D. Fine, "Development of neuroendocrine (Merkel cell) carcinoma mixed with squamous cell carcinoma in erythema ab igne," Archives of Dermatology, vol. 124, no. 1, pp. 110-113, 1988. 
[82] T. Akasaka and S. Kon, "Two cases of squamous cell carcinoma arising from erythema ab igne," Nippon Hifuka Gakkai zasshi, vol. 99, no. 6, pp. 735-742, 1989.

[83] J. B. Hewitt, A. Sherif, K. M. Kerr, and L. Stankler, "Merkel cell and squamous cell carcinomas arising in erythema ab igne," British Journal of Dermatology, vol. 128, no. 5, pp. 591-592, 1993.

[84] M. V. Iacocca, J. L. Abernethy, C. M. Stefanato, A. E. Allan, and J. Bhawan, "Mixed Merkel cell carcinoma and squamous cell carcinoma of the skin," Journal of the American Academy of Dermatology, vol. 39, no. 5, pp. 882-887, 1998.

[85] P. Boukamp, S. Popp, K. Bleuel, E. Tomakidi, A. Bürkle, and N. E. Fusenig, "Tumorigenic conversion of immortal human skin keratinocytes (HaCaT) by elevated temperature," Oncogene, vol. 18, no. 41, pp. 5638-5645, 1999.

[86] C. M. Rudolph, H. P. Soyer, P. Wolf, and H. Kerl, "Squamous cell carcinoma arising in Erythema ab igne," Hautarzt, vol. 51, no. 4, pp. 260-263, 2000.

[87] J. B. Wharton, D. J. Sheehan, and J. L. Lesher Jr., "Squamous cell carcinoma in situ arising in the setting of erythema ab igne," Journal of Drugs in Dermatology, vol. 7, no. 5, pp. 488-489, 2008.

[88] A. Böer, M. Wolter, and R. Kaufmann, "Pseudomelanoma following laser treatment or laser-treated melanoma?" Journal of the German Society of Dermatology, vol. 1, no. 1, pp. 47-50, 2003.

[89] B. S. Kim, J. B. Lee, H. S. Jang, Y. W. Kwon, K. S. Kwon, and C. K. Oh, "Multiple basal cell carcinomas arising in a port-wine stain with a remote history of therapeutic irradiation," Journal of Dermatology, vol. 31, no. 10, pp. 820-823, 2004.

[90] L. Hedelund, M. Haedersdal, H. Egekvist, M. Heidenheim, H. C. Wulf, and T. Poulsen, " $\mathrm{CO}_{2}$ laser resurfacing and photocarcinogenesis: an experimental study," Lasers in Surgery and Medicine, vol. 35, no. 1, pp. 58-61, 2004.

[91] Z. F. Jasim, W. K. Woo, M. Y. Walsh, and J. M. Handley, "Multifocal basal cell carcinoma developing in a facial port wine stain treated with argon and pulsed dye laser: a possible role for previous radiotherapy," Dermatologic Surgery, vol. 30, no. 8, pp. 1155-1157, 2004.

[92] Y.-C. Bae, Y.-S. Kang, C.-K. Oh, and S.-M. Hwang, "A report of 12 cases of basal cell carcinoma arising in lesions following laser therapy," Annals of Plastic Surgery, vol. 54, no. 4, pp. 384-386, 2005.

[93] S. S. Kelishadi, G. A. Wirth, and G. R. D. Evans, "Recalcitrant verrucous lesion: verrucous hyperplasia or epithelioma cuniculatum (verrucous carcinoma)," Journal of the American Podiatric Medical Association, vol. 96, no. 2, pp. 148-153, 2006.

[94] M.-W. Lee, S.-J. Ahn, J.-H. Choi, K.-C. Moon, and J.-K. Koh, "Pseudomelanoma following laser therapy," Journal of the European Academy of Dermatology and Venereology, vol. 20, no. 3, pp. 342-344, 2006.

[95] C. Gottschaller, U. Hohenleutner, and M. Landthaler, "Metastasis of a malignant melanoma 2 years after carbon dioxide laser treatment of a pigmented lesion: case report and review of the literature," Acta Dermato-Venereologica, vol. 86, no. 1, pp. 44-47, 2006.

[96] J. I. Na, K. H. Cho, Y. G. Kim, and K. C. Park, "Angioblastoma showing aggravation after treatment with long-pulsed Nd:YAG laser (1064 nm)," Pediatric Dermatology, vol. 24, no. 4, pp. 397400, 2007.

[97] J. Dvorácková, J. Stěrba, L. Ceganová et al., "Problems of suitability laser's excision of pigmented dermal lesions: case report of minimal deviation melanoma," Ceskoslovenská patologie, vol. 43, no. 2, pp. 64-67, 2007. 


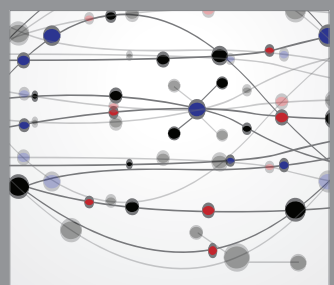

The Scientific World Journal


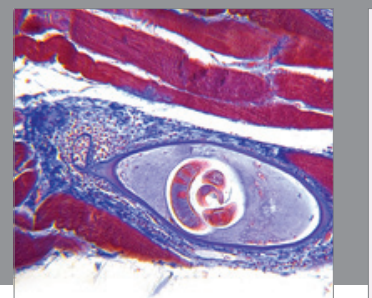

Gastroenterology

Research and Practice
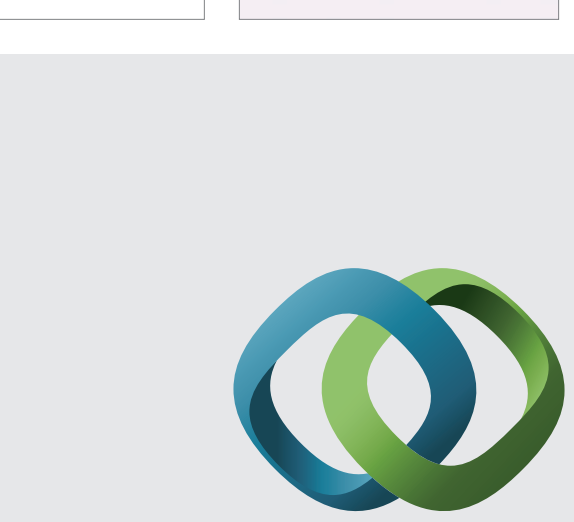

\section{Hindawi}

Submit your manuscripts at

http://www.hindawi.com

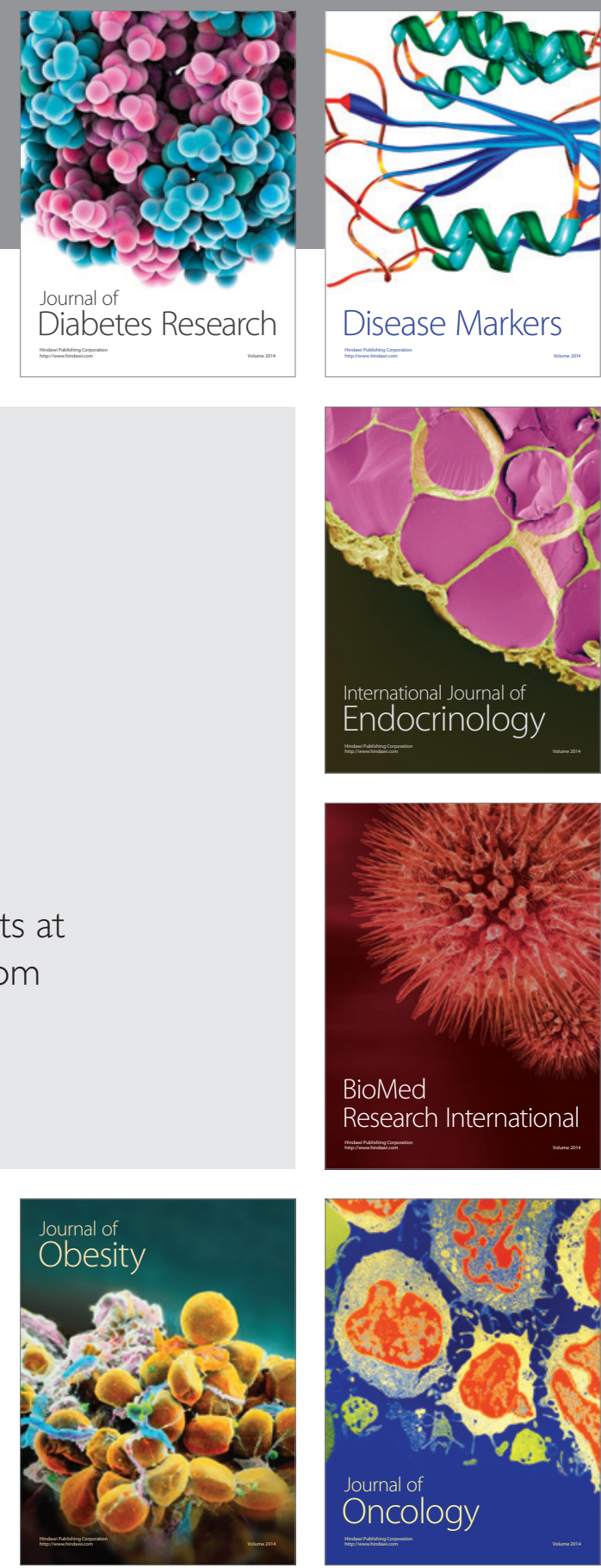

Disease Markers
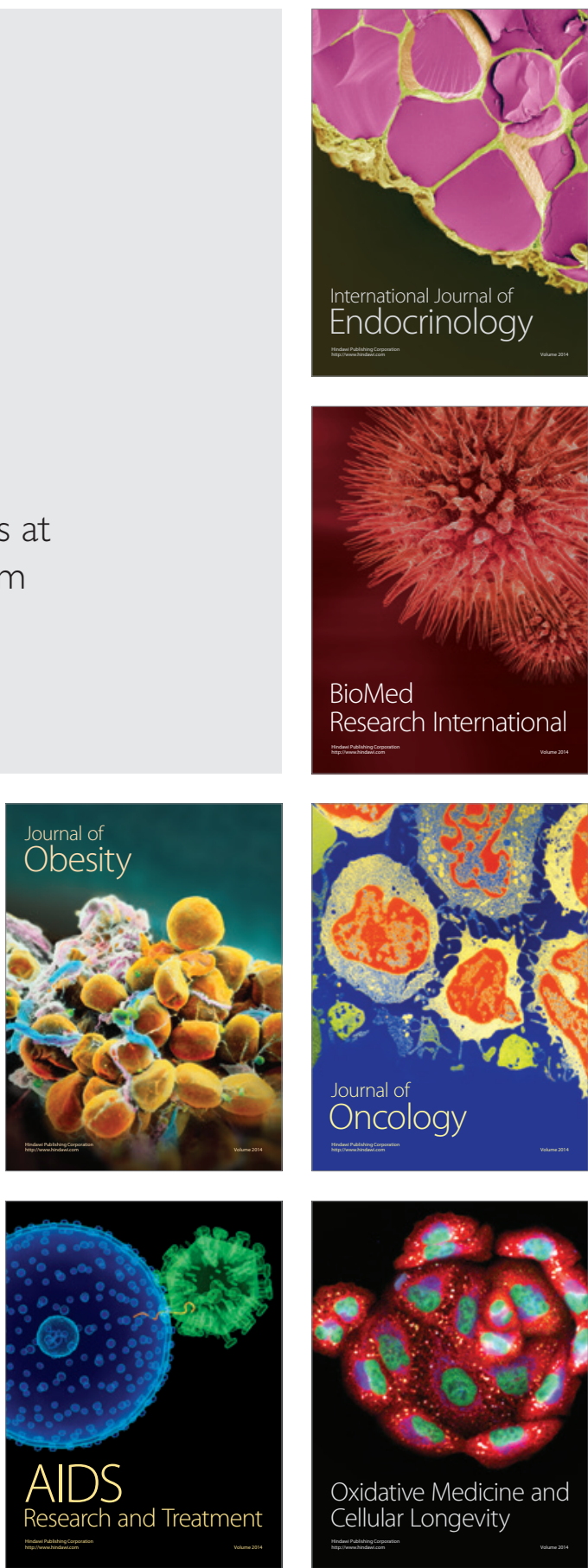